\title{
Impact of dead sea water on the mechanical properties of ferrocement
}

\begin{abstract}
The aim of the paper is to investigate the mechanical properties of ferrocement, and cement mortar to be used during casting ferrocement element, exposed to Dead Sea water. Ferrocement prisms of $600 \times 50 \times 30 \mathrm{~mm}$ and $50 \mathrm{~mm}$ cubes were cast and cured for 28 days in tap water before exposure to different Dead Sea water periods. It was observed from the investigation that there was a significant impact of the Dead Sea water on the mechanical properties of the ferrocement.
\end{abstract}

Keywords: ferrocement, sea water, mechanical properties, cement mortar, coarse aggregate, fine aggregate
Volume 4 Issue 5 - 2018

\author{
Wail N Al-Rifaie,' Esraa Alhasat, ${ }^{2}$ Waleed K \\ Ahmed $^{3}$ \\ 'Professor of Civil Engineering, Philadelphia University, Jordan \\ ${ }^{2}$ Research Scholar, College of Engineering, Philadelphia \\ University, Jordan \\ ${ }^{3}$ Mechanical Engineering Department, College of Engineering, \\ UAE University, UAE
}

Correspondence: Waleed K Ahmed, Ph.D, Mechanical Engineering Department, College of Engineering, UAE

University, UAE, Email wkh.ahmed@gmail.com

Received: May 25, 2017 | Published: September 06, 2018

\section{Introduction}

Concrete is one of the essential elements that used in different types of construction, but it has many problems when interacts with environmental such as water, air, temperature, dust and humidity. Concrete made with Portland cement, coarse aggregate, fine aggregate and water which mixed together and admixtures added sometimes to change some of properties. It is a fact that cement industries is an energy intensive process and represents $7 \%$ of worldwide energy consumption and $4 \%$ of worldwide industrial $\mathrm{CO}_{2}$ emissions. Concrete has certain characteristics; relatively strong in compression but weak in tension and tends to be brittle. These disadvantages make concrete limited to use in certain conditions. The most common problems appears on concrete are manifested by tearing, cracking, corrosion and spalling, which may lead to some defect in concrete then in the whole construction. Ferrocement is a type of thin reinforced concrete with great potential, made of cement-sand mortar and reinforced with layers of fine wire meshes with skeletal reinforcement. Ferrocement is an excellent construction material due to its mechanical properties, and low cost, and it is considered to possess a high cracking strength. Cement mortar is a material used in construction of ferrocement which is cement composite material made up of Portland cement, sand, water and sometimes admixtures.

Ferrocement is a suitable construction technology for the following reasons:

Ferrocement differs from conventional reinforced concrete in that there is a higher ratio of steel to cement mortar. By altering the mortar/ steel ratio the ferrocement material exhibits properties superior to either steel or cement mortar separately.

Ferrocement resistance is given by the geometrically shape parts.

The constituent materials of ferrocement are easily available and are quite inexpensive, labor intensity and semi-skilled labor requirements make ferrocement the most promising alternative materials for housing.

The fabrication technique of ferrocement is quite easy and common.
Heavy plants and machinery are not required in the ferrocement construction.

In case of damage, it can be repaired easily.

Ferrocement has been developed mainly during the past forty years and yet has reached a very advanced stage in technique and design. A considerable amount of laboratory testing research and prototype constructions have been completed for the production of ferrocement members that would be used in the roof/floor/wall of building/housing.

Ferrocement has a very high tensile strength to weight ratio and superior cracking behavior in comparison to reinforced concrete. Hence, Ferrocement is an attractive material for construction of shell, folded plate, ribbed slab and housing components. The growing need for "eco-housing" is much-discussed subject.

Ferrocement is an excellent construction material due to its mechanical properties, and low cost, and it is considered to possess a high cracking strength and has a number of structural applications such as earth retaining walls, swimming pools, and water tanks. In addition, the use of ferrocement in pre-fabricated buildings provides many advantages in terms of lightness of weight, ease of handling, low labor cost (skilled and non- skilled) in its production and a durable material requiring little maintenance. Al-Rifaie et al. ${ }^{1-5}$ adopted ferrocement for different application which demonstrated excellent properties for eco-buildings, fire resistance and improving the properties through using nanomaterial.

Many studies investigated the effects of using sea-sand and/or seawater as raw materials of concrete on the properties. ${ }^{6}$ Besides, the impact of utilizing the seawater $y$ on the thermal properties of mortar and concrete exposed to elevated temperature was studies experimental as well. ${ }^{7}$ Islam et al., ${ }^{8}$ presented a durability study on the effect of sea salts on structural concrete exposed to simulated tidal/ splash zone marine conditions over a period of time. The effect of Dead Sea water on pastes and mortars of normal and sulphate resisting Portland cement was studied by Heller et al. ${ }^{9}$ The present investigation is directed to study the ultimate loads of ferrocement reinforced with square welded wire mesh when exposed to Dead Sea water and to 
compare the measured values with specimens of ferrocement when exposed to the tap water under the same conditions of temperature and relative humidity. The main parameters were a number of wire mesh layers and period of exposure the specimens to Dead Sea water. ${ }^{10-13}$

The curing days for both compressive strength and ultimate loads of ferrocement prism specimens considered in the present investigation may be summarized in the following groups:

a. G1: Specimens under 28 tap water curing days.

b. G2: Specimens under 60 curing days ( 28 tap water +32 Dead Sea water).

c. G3: Specimens under 90 curing days (28 tap water +62 Dead Sea water).

d. G4: Specimens under 120 curing days (28 tap water +92 Dead Sea water).

e. G5: Specimens under 150 curing days (28 tap water +122 Dead Dea water).

The effect of Dead Sea water on cement mortar may be examined by considering; first, the factor characteristic of the Dead Sea water exposure that can affect cement mortar. Second, the element of the specific cement mortar involve, and third; the performance that should be taken to avoid undesirable performance of the cement mortar due to its interaction with Dead Sea water. The weather and climate of Dead Sea water are: hot and dry climate; average rainfall $=47 \mathrm{~mm}$; average precipitation days $=15$; average summer temperature $=27$ to $40^{\circ} \mathrm{C}$; average winter temperature $=11$ to $21^{\circ} \mathrm{C}$; average yearly temperature $=22$ to $30^{\circ} \mathrm{C}$. The morphometric data are: $\max$ length $=67 \mathrm{~km}$; $\max$ width $=18 \mathrm{~km}$; surface area $=810 \mathrm{~km}^{2}$; average depth $=118 \mathrm{~m}$; max depth $=377 \mathrm{~m}$; water volume $=147 \mathrm{~km}^{3}$; shore length $=135 \mathrm{~km}$; density $=1.24 \mathrm{~kg} / \mathrm{l}$. The main aim of this research is to investigate the behavior of ferrocement elements when exposed to the Dead Sea water and compare the measured values with bare specimens when exposed to tap water under the same conditions of temperature and relative humidity. It is concluded that ferrocement is highly affected by Dead Sea water.

\section{Experiment}

\section{Materials}

The cement used in all mixes of the present investigation was a sulfate resisting ordinary Portland cement (ASTM type II). Limestone: Crushed limestone was used as fine aggregates. The physical and chemical properties are given in Table $1 \&$ Table 2.

Table I Physical properties of limestone used in the present investigation

\begin{tabular}{ll}
\hline Hardness & 3 to 4 on Moh's scale \\
Density & 2.5 to $2.7 \mathrm{~kg} / \mathrm{cm}^{3}$ \\
Compressive strength & $60-170 \mathrm{~N} / \mathrm{mm}^{2}$ \\
Water absorption & Less than $1 \%$ \\
Porosity & Quite low \\
Weather impact & Resistant \\
\hline
\end{tabular}

Table 2 Chemical properties of limestone used in the present investigation

\begin{tabular}{ll}
\hline Lime $(\mathrm{CaO})$ & $38-42 \%$ \\
Silica $\left(\mathrm{SiO}_{2}\right)$ & $15-18 \%$ \\
Alumina $\left(\mathrm{Al}_{2} \mathrm{O}_{3}\right)$ & $3-5 \%$ \\
$\mathrm{MgO}$ & 0.5 to $3 \%$ \\
$\mathrm{FeO}+\mathrm{Fe}_{2} \mathrm{O}_{3}$ & $1-1.5 \%$ \\
Alkalies & $1-1.5 \%$ \\
Loss on ignition (Lol) & $30-32 \%$
\end{tabular}

*Limestone is impervious, hard, compact, fine to very fine grained calcareous rocks of sedimentary nature.

Lightweight fine crushed limestone was used in the cement mortar for casting ferrocement prisms and compressive strength cubes (Table 2). The grading of the limestone as given in Table 3 was conformed to the requirements of ASTM C330.

Table 3 Sieve analysis of crushed limestone considered in the present work

\begin{tabular}{lllll}
\hline Size & wtrt & $\%$ rt & Cum \% rt & \% pass \\
\hline $4.76 \mathrm{~mm}$ & 13 & 1.3 & 1.3 & 98.7 \\
$2.36 \mathrm{~mm}$ & 130.2 & 13.02 & 14.32 & 85.68 \\
$1.19 \mathrm{~mm}$ & 203.8 & 20.38 & 34.7 & 65.3 \\
$600 \mu \mathrm{m}$ & 158.2 & 15.82 & 50.52 & 49.48 \\
$300 \mu \mathrm{m}$ & 154.5 & 15.45 & 65.97 & 34.03 \\
$150 \mu \mathrm{m}$ & 157.1 & 15.71 & 81.68 & 18.32 \\
$75 \mu \mathrm{m}$ & 115.2 & 11.52 & 93.2 & 6.8 \\
Pan & 38.5 & 3.85 & 97.05 & 2.95 \\
Total & 970.5 & & & \\
\hline
\end{tabular}

*Limestone is referred to as acid sensitive. Calcareous stones are readily dissolved in acid; therefore, acidic products should not be used with limestone.

Mild steel galvanized wire meshes of square welded type were used throughout the present investigation. The average wire diameter and aperture of $0.9 \mathrm{~mm}$ and $12.7 \times 12.7 \mathrm{~mm}$ respectively. Several strands of wires were taken from the mesh and tested in tension. The average value of the yield stress $F_{y}$, ultimate stress $E_{s}$, and the modulus of elasticity $E$, calculated from the tests are $310 \mathrm{~N} / \mathrm{mm}^{2}, 610 \mathrm{~N} / \mathrm{mm}^{2}$, and $120 \mathrm{kN} / \mathrm{mm}^{2}$ respectively. The yield strength was selected as the stress corresponding to a total strain of 0.005 .

\section{Curing water}

The chemical compositions of both tap and Dead Sea water are given in Table 4.

It may be noted that the ratio of concentration of salt in the Dead Sea water is $(34.2 \%)$.

\section{Mould preparation}

The mold of ferrocement prism specimens consists of a plywood as a base and pieces of plywood sections with a thickness of $30 \mathrm{~mm}$ 
to form prisms $(600 \times 50 \times 30 \mathrm{~mm})$. Cubic molds $50 \mathrm{~mm}$ made of play wood were considered for compression tests.

Table 4 Chemical composition of Tap and Dead Sea water

\begin{tabular}{lll}
\hline $\begin{array}{l}\text { Chemical } \\
\text { element }\end{array}$ & Tap water Mg/l & Dead Sea water Mg/l \\
\hline $\mathrm{Na}$ & 45.9 & 36110 \\
$\mathrm{SO}_{4}$ & 65.4 & 420 \\
$\mathrm{TDS}$ & 438 & 341 \\
$\mathrm{CL}$ & 62.1 & 226900 \\
\hline
\end{tabular}

\section{Testing of specimens}

For the ferrocement prism specimens, the mesh was cut to the required number of layers and to the appropriate size. All materials required for each specimen with were weighed and mixed by the mechanical mixer. The crushed limestone and cement were first mixed for one minute, then the water was added and mixed for two minutes more. It may be noted that the cement: crushed limestone mix proportion used in casting the specimens was $1: 2$ by weight with water: cement ratio for all mixes was 0.4 .After cleaning and oiling the mold, the mortar layer was first spread at the base of the formwork and on top of this base layer, the first mesh was laid. The mesh layer was then covered by another layer of mortar and so on to the required number of layers and thickness. The surface of ferrocement specimens was covered with nylon sheeting. To establish mortar compressive strength fcu, a number of cubes, forty-five $50 \mathrm{~mm}$ cubes cement mortar with cement: sand ratio of 1:2 and water: cement of 0.4 were cast and tested. After 24 hours, the prism specimens and cubes were de-molded, then moist cured throughout the days of groups G1, G2, G3, G4, and G5. The cubes were tested on the same day of testing the flexural prism specimens. The average of three cubes was considered for each testing age and the compressive strength $\mathrm{f}_{\text {cu }}$ is given by $(\mathrm{P} / \mathrm{A})$, where $\mathrm{P}(\mathrm{N})$ is the maximum applied load and $\mathrm{A}$ is the surface area $\left(50 \times 50 \mathrm{~mm}^{2}\right)$. The tests were carried out according to B.S: 1881: part 116. All prism specimens have been tested with their edges simply supported over a span of $500 \mathrm{~mm}$.

\section{Results and discussion}

\section{Compressive strength fcu}

Table 5 gives the outcome of compressive strength tests. Forty five $50 \mathrm{~mm}$ cubes were cast and tested after the curing days as given in the table. The loading was applied at a rate of $15 \mathrm{MPa}$ per minute. The average of three specimens was considered for each testing age and the compressive strength $f_{c u}$ is given by $(\mathrm{P} / \mathrm{A})$, where $\mathrm{P}(\mathrm{N})$ is the maximum applied load and $A$ is the surface area $\left(50 \times 50 \mathrm{~mm}^{2}\right)$. The tests were carried out according to B.S: 1881: part 116 (Table 5).

Table 5 The measured values of cube compressive stresses

\begin{tabular}{lllll}
\hline $\begin{array}{l}\text { Curing } \\
\text { days }\end{array}$ & $\begin{array}{l}\text { Cube I } \\
\mathbf{N} / \mathbf{m m}^{2}\end{array}$ & $\begin{array}{l}\text { Cube 2 } \\
\mathbf{N} / \mathbf{m m}^{2}\end{array}$ & $\begin{array}{l}\text { Cube } \\
\mathbf{3 N} / \mathbf{m m}^{2}\end{array}$ & $\begin{array}{l}\text { Average N/ } \\
\mathbf{m m}^{2}\end{array}$ \\
\hline GI & 20 & 16 & 18 & 18 \\
G2 & 19 & 19 & 18 & 18 \\
G3 & 15 & 15.4 & 16 & 15.47 \\
G4 & 13.3 & 13.5 & 14 & 13.83 \\
G5 & 10.2 & 9.4 & 10.5 & 10.03 \\
\hline
\end{tabular}

\section{Ultimate loads of ferrocement prisms $\mathrm{Pu}$}

Table 6 gives the outcome of ultimate load tests. Ferrocement prisms were cast and tested and the measured values are given in the Table 6.

The results of the test specimens have been analyzed and presented in tabular forms. Table present the measured values of the compressive strength of cement mortar used in casting ferrocement elements for different curing days of tap water and Dead Sea water. Table presents the measured values of ultimate loads for different curing days of tap water and Dead Sea water. These tables demonstrate that the ultimate loads of ferrocement prisms and compressive strength of cube specimen's gives lower strength for longer curing periods of Dead Sea water. Test results also show that compressive strength of cement mortar is reduced when it is exposed to Dead Sea water as compared to tap water curing.

Table 6 Ultimate loads of ferrocement prism carried out in the present work

\begin{tabular}{llll}
\hline \multirow{2}{*}{$\begin{array}{l}\text { Curing } \\
\text { days }\end{array}$} & $\begin{array}{l}\text { Ultimate loads } \mathbf{P u}, \mathbf{N} \\
\text { 2-layers of } \\
\text { wire mesh }\end{array}$ & $\begin{array}{l}\text { 4-layers of } \\
\text { wire mesh }\end{array}$ & $\begin{array}{l}\text { 6-layers of } \\
\text { wire mesh }\end{array}$ \\
\cline { 2 - 4 } GI & 1667 & 1995 & 2417 \\
G2 & 1622 & 1950 & 2363 \\
G3 & 1392 & 1500 & 1670 \\
G4 & 1063 & 1320 & 1363 \\
G5 & 840 & 908 & 1005 \\
\hline
\end{tabular}

\section{Conclusion}

Based the tests carried out in the present work Dead Sea water has a significant deterioration on compressive strength of cement mortar and in turn has a significant effect on ultimate loads of ferrocement prisms.

\section{Acknowledgements}

None.

\section{Conflict of interest}

The author declares there is no conflict of interest.

\section{References}

1. Al-Rifaie WN, Mahdi OM, Ahmed WK. Development of Nanocement Mortar as a Construction Material. Advanced Materials Research. 2013;795:684-691.

2. Al-Rifaie WN, Ahmed WK, Mahdi OM. Experimental Investigation of Nano-Polymercement Composite. Study of Civil Engineering and Architecture. 2014;3:29-35.

3. Al Rifaie WN, Ahmed WK, Ibraheem LE, et al. The Use of Renewable Energy in Ferrocement Eco-Housing System. International Journal of Renewable Energy Research. 2014;4(1):151-158.

4. Wail N Al-Rifaie, Khaled K Al-Enezi. Thermal Response of Ferrocement Cavity Wall Under Direct Fire. International Journal of Sustainable Building Technology \& Urban Development. 2015;6(4):229-235.

5. Al-Rifaie W, Ahmed W. Effect of nanomaterials in cement mortar characteristics. Journal of Engineering Science and Technology. 2016;11(9):1321-1332. 
6. Jianzhuang Xiao, Chengbing Qiang, Antonio Nanni, et al. Use of seasand and seawater in concrete construction: Current status and future opportunities. Construction and Building Materials. 2017;155:1101-1111.

7. Ying-Lei Li, Xiao-Ling Zhao RK, Singh Raman, et al. Thermal and mechanical properties of alkali-activated slag paste, mortar and concrete utilising seawater and sea sand. Construction and Building Materials. 2018;159:704-724.

8. Islam MS, Mondal BC, Islam MM. Effect of Sea Salts on Structural Concrete in a Tidal Environment. Australian Journal of Structural Engineering. 2010;10(3):237-252.

9. Heller L, Ben-Yair M. Effect of dead sea water on Portland cement. J Appl Chem. 1962;12(11):481-485.
10. Abasolo R, Bandivas C, Guinita JV. Utilization of Ferrocement as Flexural Building Member (Applied as a Hollow Box Joist). Xiraadman Research Center, Xavier University, Philippines, 2009.

11. Special report. Chemical and Engineering News. 1964;42(22):1A-48A.

12. Royal Scientific Society. Environmental Research Center. Coyne-et bellier in association with tractabel engineering and kema.

13. Moinul Islam Md, Saiful Islam Md, Bipul C. Strength behavior of concrete using slag with cement in seawater environment. Journal of Civil Engineering (IEF). 2010;38(2):120-140. 